\title{
On ginseng and Iroquois
}

\section{Epistemic breaches, materiality of knowledge, and globalization in Joseph-François Lafitau (1681-1746)}

\section{Torsten König ${ }^{1}$}

Published online: 4 November 2020

(c) The Author(s) 2020

\begin{abstract}
This study is dedicated to 2 texts written by French Jesuit father Joseph-François Lafitau (1681-1746), created in the context of his missionary stay in Nouvelle France: Mémoire concernant la précieuse plante du gin-seng de Tartarie (1718) and Mors des Sauvages amériquains comparées aux mors des premiers temps (1724). Both texts permit a multi-level analysis of material dimensions of culture and knowledge in the history of knowledge, the first dealing with a botanical subject, the second an anthropological one. They convey a meta-reflective discourse on material-specific epistemological problems that is realized through narrative textual structures. These texts enable a structural view point of systemic functions of the materiality of knowledge in historical epistemological orders. Finally, they show exemplary and significant transmedia representation techniques and the associated textualization and visualization strategies.
\end{abstract}

Keywords Joseph-François Lafitau · Materiality of knowledge $\cdot$ French litterature · 18 th century $\cdot$ History of knowledge

\section{Introduction}

Material dimensions of historical objects of knowledge, their modes and functions of communication, and their contribution to epistemic orders have increasingly come into focus in recent years. ${ }^{1}$ Within the manifold research landscape on

\footnotetext{
${ }^{1}$ This focus was inspired, on the one hand, by general theorems such as those of Bruno Latour and Arjun Appadurai on the agency and social life of things and, on the other hand, by historical research such as that of Michel Foucault and Krzysztof Pomian on the formation of knowledge systems and their rules of order. An overview of the "material turn" in history and cultural studies can be found, for example in concentrated form in Ebeling (2014) and in Füssel (2015); Frenk (2012, pp. 26-37) provides a survey of the relationship between materiality and the history of knowledge.
}

Torsten König

torsten.koenig@tu-dresden.de

1 Technische Universität Dresden, 01069 Dresden, Germany 
the materiality of knowledge, there is a special field dedicated to the early modern period and the functions that material objects of knowledge assume in the profound epistemic change processes that shape this time. These processes are mainly visible in 2 historical dynamics: in the emergence of global cultures caused by the European expansion from the 16th century onwards and in the epistemological upheavals, i.e. the rearrangements of knowledge systems that characterize the period. ${ }^{2}$

Both dimensions of change shape the research work of the French Jesuit father Joseph-François Lafitau (1681-1746). During a 5 year missionary stay in Nouvelle France, from 1712 to 1717, which took Lafitau to Sault-Saint-Louis, to the southern bank of the St. Lawrence River, across from Montreal, ${ }^{3}$ the clergyman and naturalist had the opportunity to conduct intensive studies of the flora and fauna of the region as well as of the way of life of the local Iroquois tribes. He reflects on the challenges he faced in describing, categorizing, and interpreting the observed phenomena in their materiality in 2 texts he published after his return to France.

The first text deals with a botanical subject, the ginseng plant. It was published in 1718: Mémoire présenté à son Altesse royale Monseigneur le duc d'Orléans, Régent du royaume de France: concernant la précieuse plante du gin-seng de Tartarie, découverte en Canada par le père Joseph-François Lafitau, de la Compagnie de Jésus, missionaire des Iroquois du Sault Saint-Louis. The second text is entitled Mors des Sauvages amériquains comparées aux moers des premiers temps, an anthropological treatise, which was published in $1724 .^{4}$ It deals with forms of cultural expression of American Indians and compares them to those of European antiquity. The two texts permit a multi-level analysis of material dimensions of culture and knowledge in the history of knowledge. ${ }^{5}$ Firstly, they convey a meta-reflective discourse on material-specific epistemological problems in the period of upheaval between 1650 and 1750, a period that Foucault characterizes as changing from an "épistémè de la representation" to the "épistémè classique." "As will be shown, this discourse is not realized only by argumentative textual structures, but above all by narrative textual structures. Secondly, these texts allow us to observe from a structural point of view systemic functions of the materiality of objects of knowledge in historical orders of epistemology. Finally, they show exemplary and significant transmedia representation techniques and the associated textualization and visualization strategies. Following this, I will relate the results of textual analyses to the prevalent discursive

\footnotetext{
2 An overview of important fields of research and questions concerning the relationship between knowledge and materiality in the early modern period can be found in the contributions of the anthology Smith et al. (2017), the connections between globalization, knowledge, and material culture are explored in the anthologies Findlen (2013), and Gerritsen and Riello (2016).

3 The exact location corresponds to today's Kahnawake Reservation; the logistical information about his travels are given by Lafitau himself in his texts and can be seen in an edited version in the preface to the edition of 1858 (Verreau 1858), as well as in Fenton and Moore, "Introduction" (1974, pp. XXIX-XLII).

${ }^{4}$ Neither of the 2 texts come in modern editions. The quotations refer to the original editions. The Mémoire sur le Ginseng appeared in Paris in 1718 in Joseph Monge in $8^{\circ}$. The Mors des Sauvages were published in Paris in 1724 by Saugrain and Hochereau simultaneously in $4^{\circ}$ ( 2 volumes) and in $12^{\circ}(4$ volumes). The ensuing quotations refer to the edition in $4^{\circ}$.

${ }^{5}$ As yet, the texts have not yet been examined in terms of knowledge and material history.

${ }^{6}$ The transition process involved here is that described by Michel Foucault in Les mots et les choses (Foucault 1966, pp. 137-176).
} 
and historical contexts. In addition to the epistemic paradigm shift mentioned above, the influence that the drastically changing geo-cultural worldview beginning in the 16th century had on existing knowledge systems is of particular interest. Materiality gains epistemic relevance in a context in which scholars and scientists pay more and more attention to the global circulation of knowledge, culture, and goods. At the same time, another discursive field is having an effect on the knowledge production of the time-that of theology. I will also take this field into account in the subsequent reconstruction of the determinative environment of the texts.

From a historical point of view, the comparative analysis of the 2 texts, both of which have separately been the object of a number of knowledge history studies, ${ }^{7}$ contributes to a more precise placement of Lafitau in the history of botany, ethnography, and historiography. A contrastive reading will show that specific epistemic contexts, which do not necessarily dovetail with those of modern ethnology, determined the "precursor of scientific ethnology" (Fenton and Moore 1974, p. L). Finally, the botanical subject of ginseng will provide a brief glimpse into how the circulation of goods is to the circulation of knowledge.

\section{Narrating science: the visible surface of things and what it refers to}

Published in 1718 by Joseph-François Lafitau, the Mémoire sur le Ginseng, about the discovery of wild ginseng in Canada, names the Regent Philippe d'Orléans as the addressee and recipient of the dedication, as can be deduced from the complete title of the text. Publishing format and central arguments in the 80-page octavo-format text, however, hint at a broader target audience - an educated public interested in botanical, scientific, and theological questions. ${ }^{8}$

At first glance, the text seems to address 3 objectives. To start with, it tries to convince the reader of the identity of the discovered plant. Europeans had known of ginseng since the beginning of the 17th century, but its occurrence was exclusively localized to Asia. It was well known that the root had an extraordinarily high reputation in China as a healing plant and that it was traded as a valuable pharmaceutical raw material. ${ }^{9}$ The other 2 ostensible objectives of the Mémoire stem from this knowledge: it seeks to point out to the reading public both the medical and economic significance of the discovery.

\footnotetext{
7 The most important papers on the placement of Lafitau in history and knowledge history are the following: Hodgen (1964), Fenton and Moore (1974), de Certeau (1980), Duchet (1984), and Motsch (2001).

8 Jack Warwick (1996, p. 202) points to the possible political interest of the dedication on the part of the Jesuits, who, after the loss of their protection by Louis XIV, had to demonstrate their willingness to accommodate to the Regent.

9 Dutch sailors imported ginseng to Europe at the beginning of the 17th century and it became comparatively popular. Lafitau remarks about the familiarity with ginseng in Europe in his Mémoire (1718, p. 6). Aldridge (1993, p. 50) points to the fact that the usage and significance of the plant in China was introduced to the French by Jesuit missionary Louis Daniel Le Comte, Nouveaux mémoires sur l'état présent de Chine (1696) as well as by Pierre Jartoux, to whom Lafitau refers.
} 
The text is organized according to these objectives. The introductory dedication panegyric is followed by an extensive report about the circumstances of the author's discovery of ginseng. What follows is a detailed description of the plant with specifications of its morphology, occurrence, and developmental stages. As in the previous part, the argumentative pattern consists of proving the identity of the Canadian discovery with the Gin-seng de Tartarie described by Pierre Jartoux. Jartoux, himself a Jesuit monk, stumbled on the plant during his travels in Central Asia, and in 1709, he published his report about its form, occurrence, usage, and trade value in the Jesuit Lettres curieuses et édifiantes $X .^{10}$ Jartoux's text is the most important reference for Lafitau's comparative proof of identity. Lafitau also refers to it when he subsequently addresses the medical effects of ginseng as a general tonic, antipyretic, and anti-inflammatory drug and its usage in China. In a parallel strand and in an equally comparative fashion, he reports similar experiences on the part of the American Indians with the species found in Canada. Finally, he alludes to the possible economic relevance of his discovery by referring to the medical benefit of ginseng and its significance as a trade commodity in China.

At this point, a remark may be in order that the 2 species, for all their morphological agreement, are not identical, as presumed by Lafitau; rather, they belong to the same botanical family of the Araliaceae. ${ }^{11}$ There are slight differences in their medical effectiveness, which later were interpreted as a quality deficit of American ginseng vis-à-vis its Chinese counterpart. I will address the economic consequences of this difference below.

What initially strikes the reader about Lafitau's Mémoire is his comprehensive depiction of the discovery experience and the identification procedure. We can read it as a discours de la méthode, which discusses in the narrative mode central epistemological problems that preoccupied the Europe of around 1700. He claims that his chance reading of the above text by Pierre Jartoux gave him the idea that it should be possible to track down ginseng in its Canadian habitat, which resembled that of northern Asia (Lafitau 1718, p. 7f.). Lafitau describes in a detailed and comprehensive manner how he embarked on the quest for the plant, what difficulties he experienced, how he found it by chance, and how he matched the instances found with the description in word and image.

Equally voluminous is an excursus about the ensuing argument regarding the identity of his discovery, which he engages in with scholars from the Jardin du Roy and with the Académie Royale des Sciences. The occasion is the existence of other descriptions of the ginseng plant, among others by the German Asia traveller Engelbert Kaempfer in his Amoenitatum exoticarum (1712), which do not match the species found by Jartoux nor by him (Lafitau 1718, pp. 34-36). Finally, Jussieu and Vaillant had personally confirmed that Lafitau and Jartoux had described the

\footnotetext{
${ }^{10}$ Lafitau refers to Jartoux's report (1718, p. 7); for Jartoux, cf. Fenton and Moore (1974, p. XXXIV).

11 Although Lafitau is considered to be the European discoverer of the species, the nomenclature in honor of the Regent, Aureliana canadensis, which he added at the end of the Mémoire, did not manage to assert itself. In accordance with the later established system by Linné, it now bears the Latin name Panax quinquefolius, in addition to its trivial name of American Ginseng and is thus distinguished from the Asiatic ginseng Panax ginseng.
} 
"right" ginseng, the author emphasizes. The reason for Kaempfer's error is obvious to Lafitau's mind: he had not drawn up his descriptions based on personal viewing or knowledge of the physical properties of the object, but based on what reached him through hearsay from locals or from travellers. ${ }^{12}$ In contrast, Jartoux judges by experience, "Il paroist naturel au contraire de croire que le P. Jartoux qui a vû la plante en Tartarie, endroit où tout le monde convient qu'on la recueille [...] nous en a donné une figure et une idée plus juste que M. Kaempfer et les autres Auteurs qui n'y ont jamais été" (Lafitau 1718, p. 37).

Lafitau's epistemological narration proves paradigmatic for its time inasmuch as it addresses a number of important fundamental questions concerning the philosophy of science between empirical knowledge, the degree of authority of a text, and the quest for appropriate knowledge storage or appropriate media for the communication of knowledge. In early-eighteenth century, scholars and scientists increasingly considered experience-based viewing and exact knowledge of the physical condition of the object as the only way to obtain reliable knowledge. Reference quantities for this knowledge are the observer in the form of a witness or guarantor as well as the measurable surface of things, or putting it differently, their materiality. ${ }^{13}$ The text assigns a prominent place to both.

The observer is highly visible in Lafitau's text in form of the first-person narrator, who determines the point-of-view of this observer. Resorting to narrative techniques, such as the use of plot protagonists and the development of goals of action or conflicts, comes across as a plausible move at this point. Such narrative techniques lend themselves well to the modelling of experience processes.

The materiality of the object in question shifts into focus insofar as it takes on a decisive part in the narration of the identifying process. Attempts to create verbal evidence repeatedly fail in the narration, for example when the missionary, using his poor descriptions, tries in vain to involve in his quest natives familiar with the locale, or when Kaempfer's findings are falsified due to inadequate verbal communication. In contrast, procedures that yield an adequate media representation of the empirically experienced surface of an object bring about the desired certainty. The Planches attached to the text by Jartoux, which feature image plates of the plant, led to an immediate identification by the natives (Lafitau 1718, p. 16). A sample of the plant preserved in alcohol was sent to Jussieu in Paris in hopes that "la comparaison qu'on feroit de cette planche et de cette Lettre avec la plante entiere [...] suffuroit pour en convaincre [i.e. of its identity, NB by the author] d'un seul coup d'œil" (Lafitau 1718, p. 33). After his return to Paris, the author achieved even greater certainty than through the visual image by a first-hand comparison of the samples of Chinese ginseng with its American counterpart, which are preserved in Paris (Lafitau 1718, p. 34).

\footnotetext{
12 "Il paroist donc vrai-semblable que tous les Auteurs qui nous ont donné des figures différentes de cette plante, ne nous les ont données que sur des memoires infideles, trompez eux-mêmes par d'autres qui l'avoient été avant eux" (Lafitau 1718, p. 38).

${ }^{13}$ Regarding the philosophy of science of the century, see Chapter II.1, "Le nouvel esprit scientifique," Roger 1993, pp. 163-254.
} 
The role attributed to experience and to the primacy of the visible as an evidence criterion in the epistemological process points to the episteme of the classical age, which Michel Foucault considered the epistemological dispositive for the 18th century. It is characterized by a focus on the visible and measurable surface of things with the goal of identifying their distinctive features and of making their classification possible, which is the ultimate epistemological goal of natural history (cf. Foucault 1966, pp. 137-176). The detail with which Lafitau dramatizes his verification procedure may be regarded as an indicator for the epistemic paradigm shift leading up to the episteme of the classical age. Hardly 2 decades later, Linnaeus was to publish the first edition of his Systema naturae (1735), which elevates the techniques of measuring, describing, and comparing as discussed by Lafitau into the ranks of systematic methods.

The focus on visibility in the text leads to a greater emphasis on the materiality of natural phenomena as an epistemic criterion. Insofar as natural history focusses on the spatial dimensions of things as measured by the parameters of shape, number, relative position, and relative size (cf. Foucault 1966, p. 146), aspects of materiality will receive the limelight. The media techniques by which materiality is communicated are a description based on accurate observation, which can represent these aspects; visual representation techniques such as the Planches, and lastly the sample itself. The material touchstones assume a role as "silent messengers" 14 of knowledge. They circulate amongst the actors within knowledge cultures and bridge the gap between far-apart areas. The sample is sent to Paris, and the transposition of the morphology into the media of figure plate and text would be disseminated by the Lettres curieuses et édifiantes in the global network of Jesuit missions. ${ }^{15}$ Finally, the samples are measured, classified, and integrated into the cabinets of natural history, and their descriptions are translated into nomenclatures. The cabinets are, as a part of the "ordre matériel du savoir," the material equivalent to the nomenclature; both claim to represent the order of nature. ${ }^{16}$

\section{Theology and knowledge}

Another, hitherto unnoticed, dimension of the epistemic relevance of the materiality of knowledge in Lafitau becomes apparent if we look closely at the theological subtext. This subtext provides the underpinnings of his natural-history-based

\footnotetext{
14 The term is used by Dupré et al., (2011) in their anthology Silent Messengers. The Circulation of Material Objects of Knowledge in the Early Modern Low Countries to describe the communicative function of material things that circulate in economic networks or networks of knowledge worldwide: "[...] they are silent messengers because they didn't speak, but needed to be spoken about; and because they usually didn't carry a text, but rather led to the production of texts, with human agents bringing about their integration into the scholarly discourse" (ibid. p. 1).

15 Warwick (1996, p. 203) regards this kind of letter as a "véritable instrument d'exploration mondiale."

16 Françoise Waquet (2015) uses the term of „ordre matériel du savoir“ to describe the material and tangible dimensions of knowledge production, communication and storage in the process of the formation of the modern scientific system since the 16th century; for cabinets and collections, see Pomian (1987).
} 
argumentation. The author states that the Tartarian name for ginseng as attested by Jartoux has the same meaning as the corresponding word in the language of the Iroquois, humanlike or leg of the human being (Lafitau 1718, p. 16). This similarity, as well as the fact that the plant occurs both in America and in Asia is, to him, evidence for the common origin of the residents of both continents as well as, by analogy, for the physical connection between America and Asia (ibid., pp. 17-18). ${ }^{17}$ To what extent Lafitau's theses were correct according to today's state of the art is not relevant here. Rather, the question arises as to what type of epistemic contexts informed his attention and determined his lines of argument, his reasoning strategies, and his ways of articulating his ideas.

Theological relevance can be attributed to Lafitau's argumentation in the context of the contemporary discussions about a common origin of the whole of humanity, i.e. the question of a consensus gentium, and the question of the universality and naturalness of religion, i.e. the prisca religio (cf. Krist 1995). Developed as a proof of the existence of God by patristics, this theory experienced a renascence in the theological and anthropological discussions starting with the 16th century. The reason is not only a demand for rhetorical ammunition in the context of counter-reformation, but ostensibly also the need for explanations necessitated by the "discovery" of ever more unknown peoples and cultures in the New World. Scholars and scientists have discussed whether these were human beings or animals, and whether they had a religion, since the first discoveries and their corresponding theological, anthropological, and legal implications (cf. Pagden 1987). Around 1700, monogenistic theories were enjoying a hey-day in counter-reformatory apologetics. In Lafitau's formative years, 2 of the most influential French theologians-Jacques Bénigne Bossuet with his Discours sur l'histoire universelle (1681) and Pierre Daniel Huet with his Demonstratio evangelica (1672)-belonged to the advocates of this doctrine. Lafitau himself devotes his magnum opus, the Mors des Sauvages Amériquains, ${ }^{18}$ to this, as will be discussed in more detail below. Even if explicit discussion of the topic takes up comparatively little space in the Mémoire, the contexts sketched, and the central position that this question was to take on in his later work, give enough reason to presume that this aspect was a central motivation for his Mémoire already, even if it is not as obvious there. ${ }^{19}$

\footnotetext{
17 A possible land connection between Asia and America remained largely uncertain during Lafitau's life time. Even after the western shore of America had been explored since the beginning of the 16th century and Magellan had confirmed in the years of 1519-22 that the continent was separated from Asia by a vast ocean, the North of America and Asia were terra incognita for the Europeans at the beginning 18 th century as, for example, Guillaume Delisle's map of the world from 1707 shows. Thus, a land connection remained in the realm of the possible. That there was definitely no land bridge between the continents was only proven by Vitus Behring in 1741.

18 On the influence of Bossuet and Huet on Lafitau, cf. more extensively Fenton and Mooree 1974, pp. LIII-LV.

19 Proof thereof is also a brief report about the ginseng finding in Canada, which Lafitau published immediately after his return in January 1717 in the Journal de Trévoux. This short article, too, invariably features the pointer to a kinship of the North American and Asiatic peoples. Cf. on this and on the role of the monogenistic doctrine for the Mémoire, Aldridge 1993, pp. $49 \mathrm{ff}$.
} 
Against this backdrop, the prominent materiality of objects of knowledge, which Lafitau makes the subject of his Mémoire (i.e. the salient role of measurable surfaces as the touchstone of knowledge), gains another dimension of meaning. They become signs that point back to an unavailable origin. The ginseng plant is not only a botanical object with medical and economic relevance but, as materially tangible evidence, refers back to an absent signifié. The discussion is not about genealogies and evolutions, but about simultaneity. Space is the ordering frame of the new episteme, natural history enquiring about the place of a phenomenon in the plan of creation. What makes the Mémoire interesting and paradigmatic in this regard is that it combines the theological origin argument with a subject from natural history and thus conjures up a problem from the history of knowledge, with which the former is connected-that of the continuity of creation (cf. for this as a central question of natural history, Foucault 1966, pp. 158-170, and Ehrard 1963, pp. 186-198). It turns out to be the determinant for the comparative method, which informs both the Mémoire and, to an even greater extent, the Mors des Sauvages.

Europeans had known well the doctrine of the continuity of nature since Aristotle. According to it, natural history presents itself as an uninterrupted order, without any leaps or gaps; an order that is able to integrate any existing object. Alexander Pope popularized it in the 18th century through the idea of the "chain of beings." The doctrine was becoming the focus of attention in the knowledge system of the classifying and ordering age of Tournefort and Linnaeus. ${ }^{20}$ Together, the case of Lafitau's ginseng discovery and the compilation of elements in the accompanying epistemic narration (the geographical localization, the resultant questions) turned attention to this central problem in 18th century knowledge history, which is the "chain of beings." In Lafitau, the discovery of new overseas geographical, geo-botanical, and geo-anthropological spaces proves to be a source of theological problems, insofar as they call the continuity of creation into question. The origin of species and peoples detected in these spaces called for other plausible explanations in a time that did not have any concept of evolution yet. Lafitau's proposal for a solution of the problem involves using the comparison of species to determine their identity, and postulating an originally continuous space. This procedure requires the evidence of visibility and materiality. Comparison as the central operation of a proof of coherence is based on a precise knowledge of measurable surfaces and an adequate documentation of data. Due to the knowledge system's actors "circulating" to expanded geographical horizons, knowledge in 18th century sciences becomes more strongly bound to space, while at the same time, material manifestations of knowledge (samples or visual representations) acquire a greater significance as vehicles of information and, hence, media of communication within the knowledge system. These developments are the subject of Lafitau's narration about his ginseng discovery in Canada.

\footnotetext{
20 Alexander Pope's Essay on man appeared in 1732-34 and highlights the popularity of the idea of the chain of beings. Cf. Ehrard (1963, p. 191) and Lovejoy (1936).
} 


\section{Customs of people: collecting, comparing, organizing}

As a botanist, Lafitau applied the comparison method developed with the object of ginseng (including the same theological implications and under the same epistemic conditions) to another subject area that could not be further removed from botany, namely anthropology. In 1724, he published the Mors des Sauvages amériquains comparées aux mors des premiers temps (this text, too, is devoted to the Duc d'Orléans, most likely for the same reasons as the Mémoire). The impetus for the undertaking, according to the author in his preface "Dessein and Plan de l'Ouvrage," was his experience in his contacts with the natives during his missionary work: "Le séjour que j'ai fait parmi les Iroquois, m'a engagé à détailler plus particullierement leurs Mœrs, parce que je les connois mieux, and que je suis plus assuré de ce que j'avance" (Lafitau 1724, I, p. 25). The actual goal of the treatise, however, goes far beyond a simple documentary intention, since he was intent on proving the common genealogical origin of the "Sauvages amériquains" and Europe's ancient peoples. According to Lafitau, North America's "sauvages" are descendants of the peoples "qui occupèrent le Continent de la Grèce and ses Isles, d'où [...] ils furent obligez d'en sortir enfin tous, ou presque tous, pour se répandre en divers païs" (ibid., pp. 89-90). He argues that colonization and settlement of North America started from Greece and its neighbouring countries and continued successively via the land connection (ibid., pp. 3-34). As he concedes, there can only be "conjectures assez vagues" about the circumstances of colonization and settlement during his time. Therefore, he chooses a form of proof that only allows for indirect conclusions about the unavailable origin: "[...] il suffit de montrer dans tout le détail des Mœrs des Ameriquains une si grande uniformité avec les Mœrs des premiers Peuples, qu'on en puisse inferer qu'ils sortent tous d'une même tige" (ibid., p. 19). On more than a thousand pages and in 41 figure plates, he compares the Sauvages amériquains and the ancient peoples systematically for what he calls moers. He describes cultural manifestations in the form of objects, social practices, policies, symbols, and rites from all areas of societal life: religion, government, marriage, child rearing, tradeswork, war, commerce, hunting, games, medicine, death and mourning, and language. The collected ethnographic data act as a procedure of evidence of the alleged relationship. Within this procedure, Lafitau draws on 2 sources of knowledge: experience - his own and that of authenticated witnesses - and writings - the rich travel literature to the New World and the historiographical writings concerning the ancient world. ${ }^{21}$

His interest in the diversity of areas of life, his careful attention to the concrete manifestations of cultures, and his comparative method led scholars of the twentieth century to declare Lafitau a precursor of modern ethnography. ${ }^{22}$ However, without

\footnotetext{
${ }^{21}$ For his sources, cf. the preface, "Dessein et plan de l'ouvrage" (Lafitau 1724, pp. 2-3 and 25) as well as Fenton and Moore (1974, pp. XIX-CXIX).

22 Fenton and Moore (1974, pp. LXXVI-LXXXIII) discuss Lafitau's role as a precursor of modern comparative anthropology in detail, elsewhere (p. XXIX) citing Alfred R. Radcliffe-Brown, who regarded Lafitau as "one of the precursor of social anthropology" Duchet (1984, p. 30) underlines that Lafitau has made the "mœrs" the subject of a new discourse, "entièrement fondé sur la comparaison, seule raison du
} 
analyzing the epistemic determinants of Lafitau's work sufficiently, one runs the risk of judging his place in the history of knowledge anachronistically from a modern perspective. Below, I will try to demonstrate that Lafitau's interest was not ethnographic in the modern sense of the term.

A closer look at the contexts shows that his project was in no way unusual during his time. I have already hinted at the prevalence of the monogenistic doctrine as an element in the apologetics of Bossuet or Huet, amongst others. Lafitau explicitly refers to them in his Mors des Sauvages, partially in a critical vein $(1724, \mathrm{I}, \mathrm{p} .12){ }^{23}$ Thus, the text inscribes itself into the same apologetic horizon as the Mémoire sur le Ginseng. The concrete historical requirements for this to happen are similar to those for the previous paper: on the one hand, the precarious situation of the Jesuits; on the other hand, the general fight against religious sceptics and free spirits. ${ }^{24}$

Even Lafitau's speculations about a settlement of America by land by ancient people are by no means original or new. It can be found in Hugo Grotius, De origine gentium Americanarum dissertatio (1642), whom Lafitau (1724, I, p. 33) quotes. Finally, that comparison between antiquity and modernity marked the intellectual debates of the time; the Querelle des Anciens et des Modernes is not the only proof thereof. Linking ancient and modern paganism was, to all intents and purposes, common practice; see for instance Fontenelle's treatise De l'origine des fables shows, which appeared in 1724, i.e., in the same year as Lafitau's Mors des Sauvages. In it, Fontenelle compares Greek mythology with the mythology of North America's native people. ${ }^{25}$

As far as ethnographic material about the New World is concerned, Lafitau did not break any new ground. He had access to a variety of compilations of this material: cosmographic and historiographic compendia such as the Cosmographie universelle (1571) by André Thevet or Marc Lescarbot's Histoire de la Nouvelle-France (1609) and numerous travelogues, such as Jean de Léry's Histoire d'un voyage faict en la terre du Brésil (1578). However, comparing the structural peculiarities of Lafitau's text with the travelogues and other compendia about the New World, including contemporary ones such as those of Jean-Baptiste Labat, Nouveau Voyage aux Isles de l'Amérique (1722) or François-Xavier de Charlevoix, Histoire et description

\footnotetext{
Footnote 22 (continued)

texte." On the role of ethnology, see Feest (2001), for the most comprehensive discourse-archeological discussion of Lafitau's role for modern ethnology, cf. Motsch 2001.

23 In theologians of the 16th and 17th century, such as Vossius, Kircher, and Borchart, there are contemplations of a common origin of the ancient peoples in connection with Old-Testament genealogies. Cf. Gossieaux (1995, pp. 311-346).

24 Amongst the latter, Lafitau (1724, I, p. 111) has singled out the Baron de Lahontan, who, in his extremely popular Dialogues entre l'auteur et un sauvage de bon sens qui a voyagé (1703) develops an image of the Native Americans' religiousness, which is diametrically opposed to that of Lafitau.

25 Lafitau (1724, I, pp. 1-2.) himself points out the parallelization of antiquity and the present during his time The juxtaposition of Lafitau and Fontenelle runs through a number of studies, see Boch (2003). Similar ideas have been developed by Pierre Bayle in his Dictionnaire historique et critique (1697). Free spirit François de La Mothe le Vayer, in his La Vertu des paiens (1641) draws a comparison between the Chinese, indigenous North Americans, and the ancient Greek in order to prove similarities between them. On the comparison between antiquity and modernity, see Hodgen (1964, pp. 295-353).
} 
générale de la Nouvelle France avec le Journal historique d'un voyage fait par ordre du Roi dans l'Amérique septentrionale (1744), the special character of Lafitau's undertaking becomes apparent. He does not organize his material according to the structure of an itinerary. Unlike in a travelogue or in his Mémoire sur le Ginseng, the mediating agent is not only not modelled, but also not tangible. In contrast, the text is organized based on a systematic comparison of cultures, making it, in its consistent rigorousness, a hitherto unique case. In the systematicity of his comparison, he distinguishes himself from both travelogues and existing comparative compilations of the past and of his present, from the Histoire naturelle of Plinius through De la Créquinière's Conformité des coutumes des Indiens Orientaux, avec des Juifs et des autres Peuples de l'Antiquité (1704). ${ }^{26}$ On the basis of this organization, Lafitau, as Michèle Duchet underscores, makes the mors the subject " $d$ ' un discours nouveau, entièrement fondé sur la comparaison, seule raison du texte" (Duchet 1984, p. 30).

If one looks for epistemic determinants for Lafitau's choice, against the background of the observations on the Mémoire sur le Ginseng, these can be found in contemporary efforts for order and the efforts to systematize knowledge (cf. Foucault 1966, pp. 152-3). From a theological point of view, the Mors des sauvages prove to be marked by the doctrine about the continuity of creation. On the one hand, the central problem of the treatise is the genealogy of the Sauvages Amériquains, and thus their place in the history of salvation, which are problems of the continuousness of natural order. The Native American represents a lacuna in the systematic order of text-based Christian anthropology. ${ }^{27}$ On the other hand, Lafitau's will for order extends to a diversity of cultural objects that are at his disposal for his reasoning. "J'ai tâché de garder une certaine méthode," he describes his approach in programmatic wording, "enchaînant les choses ; and leur donnant une telle liaison, qu'elles paroissent suivre l'une de l'autre" (Lafitau 1724, I, p. 18). While the universalism of the Bible's history of salvation appears to be a special theological problem, Lafitau's methodological annotations about the totality of his collection of individual objects show commonalities with the problems of contemporary natural history. His approach converges with the classifying efforts of a Tournefort or Linnaeus; as like them, he ascertains identities "par le résidu des differences" (Foucault 1966 , p. 157) based on methodical comparison. The goal of the histoire naturelle is to create a coherent, uninterrupted conceptual order that corresponds to the natural order of things. The goal of the Mors is to compare and systematize mythological figures, rites, and social practices in order to prove their belonging to one and the same order of religious or general cultural manifestations.

The materiality of cultures that are the subject of Lafitau's research interests plays a twofold part in the generation of his comparative system. First, artefacts, due to the comparability of their physical manifestations, are often the starting point for

\footnotetext{
${ }^{26}$ Lafitau himself reflected on this difference. "J'ai lu aussi les Relations qui ont été données au public," he writes about his sources, in order to vehemently criticize them in the same breath: "Ce n'est pas une vaine curiosité et une connaissance stérile que doivent se proposer les Voyageurs qui donnent des Relations au Public" (1724, I, pp. 3-4)

27 About the place of the Native Americans in Christian anthropology, see Pagden 1987.
} 
further conjectures. For instance, the author develops parallels between ancient music and festival culture and that of the Sauvages by comparing the shape, material, and construction of Indian rattles with similar instruments from antiquity, such as the sistrum (Lafitau 1724, I, pp. 209ff.). Insofar as Lafitau focusses the visible and measurable dimensions of material objects, his approach corresponds to the basic operations of the episteme of the classical age (Foucault 1966, pp. 144-150). The numerous figure plates added to the text play an important part, in that they are not simply illustrations but, as representations of cultural artefacts transposed into a different medium, act by way of the character of their visual evidence. Thus, 2 plates showing the instruments in different cultures (Planche 8, I, p. 212, and Planche 9, I, p. 216) supplement the comments on the Indian rattles. In parallel to the role that Lafitau ascribes to the turtle as a mythological element in Native American genesis, the figures from Planche 1 (I, p. 94) and their corresponding explications show motives from Greek, Egyptian, and Indian mythology that attest to the universality of the figure (I, pp. 93ff.). The reproductions stem from various sources, among others from the Jesuit library canon like the Oedipus Aegyptiacus (1652-55) by Athanasius Kircher and from popular contemporary plate compilations of ancient material relics such as the Romanum Museum sive thesaurus eruditae antiquitatis (1690) by Michelangelo de la Chausse (the sources of the figures are listed at the beginning of each volume in the extensive "Explication des Planches et Figures"). Michel de Certeau remarks on the epistemic function of these plates, they "form an iconic discourse which traverses, from one section to another, the mass of the written discourse." 28

The fact that the materiality of things is brought to the focus of attention by the descriptions and illustrations in Lafitau's works, is thus determined by those epistemic contexts of the 18th century in which the visibility and measurability of the phenomena was assigned a decisive epistemological role. Against the background of the apologetic intention of the treatise and the semiotic structure of the evidence procedure associated with it, another dimension of the systematic comparison order emerges. The phenomena that can be experienced in their materiality refer, like the ginseng in the Mémoire of 1718, to something that cannot be experienced or available-the common origin of cultures and thus of peoples buried in history. By collecting and comparing the artifacts available to him, Lafitau shows something that is not (or no longer) visible in their visibility. ${ }^{29}$ Quite in line with the cumulative logic that the author uses for the procedure-this is where the Mors des Sauvages differ from the botanical study - the apologetic authority of the collection increases in tune with its volume. The sheer number of parallels between antiquity and the New World shown by individual objects is in Lafitau a cogent argument for the correctness of the thesis about a common origin. Thus, it is clear that Lafitau has described

\footnotetext{
28 De Certeau, 1980, p. 40. Comprehensively on the function of the etchings in Mors des Sauvages, see Paschoud (2008).

29 "These figures [...] have the force of authorities, inasmuch as they conserve a visibility of origins. [...] To recall the expressions tirelessly repeated by Lafitau, these figures allow us to see or to glimpse the beginnings of history," Certeau (1980) states, however, in 1980, p. $41 \mathrm{f}$.
} 
"these cultures in terms of themselves" and should therefore be regarded as "the first of the modern ethnographers" (Fenton and Moore 1974, p. L), even if his motivation for the collection of ethnographic data is worlds apart from that of modern ethnographers.

\section{Epilogue on the circulation of culture and knowledge and conclusions}

The texts by Lafitau discussed above both deal with the circulation of culture and knowledge in the time of "early modern globalization." Based on empirical comparisons between natural objects and artefacts, they speculate about historical ways of spreading culture and knowledge. Despite the speculative character and even if the motivation is theological in nature, the context of European expansion from the 16th century onwards becomes tangible as a determinant for the choice of objects and the questions. The texts are a reflex of the interactions between an extension of the geographical and, accordingly, the anthropological, cultural, and scientific horizons, on the one hand, and of the choice of subjects of knowledge, the questions posed, and the media systems, on the other hand. These contexts also become tangible if one looks at the reception of the knowledge that unfolds in Lafitau's texts.

The Mémoire sur le Ginseng did not manage to awaken the interest of the French in the botanical trouvaille, either from a medical point of view, or from an economic perspective. An explanation for the lack of medical interest lies in the same epistemic contexts that have determined the form and subject of the Mémoire. While the method of a scientific approach to the Canadian discovery turns out to be shaped by the new knowledge system of taxonomies, the explanation of medical effectiveness still appears strongly influenced by the old episteme of representation (cf. Foucault 1966, pp. 60-91). Apart from reported testimonials, the text does not manage to give any plausible explanations about the effectiveness of ginseng. Instead, there is a reference to the "Indian" and the "Chinese" episteme: the human-like shape of the plant appears to be an indicator of its therapeutic effect (Lafitau 1718, pp. 16 f., 44 ff.). The contemporary scepticism regarding the healing power of ginseng becomes evident in the article "Gin-seng" published around the middle of the century in the Encyclopédie by Louis de Jaucourt. Jaucourt points out the speculative character of Lafitau's claims.

Furthermore, the European readers of Lafitau did not recognize the economic potential of the discovery for the trade with China. As the representative of French trade interests, the Compagnie des Indes permitted the establishment of wild ginseng trade between Québec and Canton at the beginning of the century. ${ }^{30}$ Within a few decades, however, a highly lucrative trade developed. The Chinese paid at the time 25 francs per livre in comparison with a wholesale price in Canada of 2 francs. In 1752, the Canadian-Chinese ginseng trade amounted to 500000 francs. The run on Canadian ginseng, in which the Compagnie des Indes now also participated

$\overline{30}$ The dates of the ginseng trade development can be found in Verreau (1858), pp. 5-10. 
with a price war, however, led to an unprecedented depletion of stocks, which were almost completely destroyed in 1754 .

A few years later, trade came to a standstill, above all due to the increasingly low quality of the exported roots. ${ }^{31}$ This half-forgotten spectacular case of early global economic history would lend itself superbly to investigating the dynamics of a globalized economy; a desideratum for a further interdisciplinary study. The only thing to note at this point is that the global circulation of knowledge goes hand in hand with the global circulation of commodities. The latter would be a further subject for the investigation of the connections between the materiality of culture and cultural transfer.

The effective reception history of the Mors des Sauvages turns out to be different from that of the Mémoire. Even though the 2 volumes were a big commercial publishing success, the author experienced comparatively little positive response from the great thinkers of his time (cf. Fenton and Moore 1974, p. LXXXIII). A single mention of his name is made by Voltaire in his Essai sur les mours et l'esprit des nations (1754), yet exclusively in the form of a satirical slam. This fierce critic of church dogmas may not have been the only one to reject the Jesuit for the ostentatiousness of his apologetic intentions. The mockery of Voltaire also reveals another motive for the reluctance. While he was not able to see the innovative potential of Lafitau's descriptive and comparative approach, his comments indicate that he suspected Lafitau of reasoning in the categories of an utterly obsolete episteme: "Laissons le père Lafitau fair venir les Caraibes des peuples de Carie, à cause de la conformité du nom, [...] laissons-le supposer que les Caraïbes ne naissent rouges, et les Négresses noires, qu'à cause de l'habitude de leurs premiers pères de se peindre en noir ou en rouge" (Voltaire 1963, p. 24).

In contrast, with the present study I hope to have elucidated that Lafitau's proceeding is indeed very much determined by the episteme of the classical age inasmuch as he sets up orders of things based on a systematic comparison. In doing so, he establishes the fundamental principles of modern ethnology: collecting, describing, comparing, and interpreting. The material manifestations of culture take on a special role here. With their reference structure, they give the immaterial and unavailable dimensions of culture a tangible, tangible presence. One of these dimensions is that of "origin." Similar to Lafitau, modern ethnology proves to be driven by the myth of an origin. While the Jesuit monk's quest for the latter has theological motivations, the interest in primitivism and primordial cultures on the part of comparative anthropology since the 18th century appears to have been guided by modernity's criticism of progress. This may possibly be the reason why, Jean-Jacques Rousseau, rather than Lafitau, was declared "père de l'ethnologie" (Lévi-Strauss 1963).

Funding Open Access funding enabled and organized by Projekt DEAL.

\footnotetext{
31 Only in the second half of the 18th century do Americans start to revive the trade of ginseng and manage to expand it in the 19th century; cf. Aldridge (1993, pp. 57-65).
} 
Open Access This article is licensed under a Creative Commons Attribution 4.0 International License, which permits use, sharing, adaptation, distribution and reproduction in any medium or format, as long as you give appropriate credit to the original author(s) and the source, provide a link to the Creative Commons licence, and indicate if changes were made. The images or other third party material in this article are included in the article's Creative Commons licence, unless indicated otherwise in a credit line to the material. If material is not included in the article's Creative Commons licence and your intended use is not permitted by statutory regulation or exceeds the permitted use, you will need to obtain permission directly from the copyright holder. To view a copy of this licence, visit http://creativecommons.org/licen ses/by/4.0/.

\section{References}

Aldridge, A. O. (1993). Lafitau and that precious root: Ginseng. In A. O. Aldridge (Ed.), The dragon and the eagle. The presence of China in the American Enlightenment (pp. 47-65). Detroit: Wayne State University Press.

Boch, J. (2003). L'Occident au miroir des sauvages: Figures du païen chez Fontenelle et Lafitau. Tangence, 72, 75-91.

de Certeau, M. (1980). Writing vs. time: history and anthropology in the works of Lafitau. Yale French Studies, 59, 37-64.

Duchet, M. (1984). Le Partage des savoirs. Discours historique, discours ethnologique. Paris: La Découverte

Ehrard, J. (1963). L’idée de nature en France dans la première moitié du XVIIIe siècle. Paris: Albin Michel.

Dupré, S., Lüthy, Ch., \& Herbert, (Eds.). (2011). Silent messengers. The circulation of material objects of knowledge in the early modern Low Countries. Münster: LIT Verlag.

Ebeling, K. (2014). Kulturwissenschaft. In S. Samida, M. K. H. Eggert, \& H. P. Hahn (Eds.), Handbuch Materielle Kultur (pp. 293-298). Stuttgart/Weimar: Metzler.

Feest, Ch. F. (2001). Father Lafitau as ethnographer of the Iroquois. Native American Studies, 15(2), 19-25.

Fenton, W. N., E. L. Moore (1974). Introduction. In Fenton and Moore (Eds.), Customs of the American Indians compared with the customs of primitive times by Father Joseph François Lafitau, edited and translated, in two volumes (vol. I, pp. XXIX-CXIX). Toronto: The Champlain Society

Findlen, P. (Ed.). (2013). Early modern things. Objects and their histories, 1500-1800. London/New York: Taylor and Francis.

Frenk, J. (2012). Textualised objects. Material culture in early modern English literature. Heidelberg: Winter.

Füssel, M. (2015). Die Materialität der Frühen Neuzeit. Neuere Forschungen zur Geschichte der materiellen Kultur. Zeitschrift für historische Forschung, 42, 433-463.

Foucault, M. (1966). Les mots et les choses. Paris: Gallimard.

Gerritsen, A., \& Riello, G. (Eds.). (2016). The global lives of things. The material culture of connections in the early modern world. London: Routledge.

Gossieaux, P.-P. (1995). L'Homme et la nature. Genèses de l'anthropologie à l'âge classique (15801750). Bruxelles: De Boeck Université

Hodgen, M. T. (1964). Early anthropology in the sixteenth and seventeenth centuries. Philadelphia: University of Pennsylvania Press.

Krist, M. (1995). Kultur, Zeit und Anthropologie in J.-F. Lafitaus Mors des sauvages ameriquains (1724). Romanistische Zeitschrift für Literaturgeschichte, 19, 21-41.

Lafitau, J.-F. (1718). Mémoire présenté à son Altesse royale Monseigneur le duc d'Orléans, Régent du royaume de France: Concernant la précieuse plante du gin-seng de Tartarie, découverte en Canada par le père Joseph-François Lafitau, de la Compagnie de Jésus, missionaire des Iroquois du Sault Saint-Louis. Paris: Joseph Monge.

Lafitau, J.-F. (1724). Mœrs des Sauvages amériquains comparées aux moers des premiers temps. Paris: Saugrain and Hochereau

Lévi-Strauss, C. (1963). Rousseau, père de l'ethnologie. Le Courrier, 3, 10-15. 
Lovejoy, A. O. (1936). The great chain of being: A study of the history of an idea. Cambridge, Massachusetts: Harvard University Press.

Motsch, A. (2001). Lafitau et l'émergence du discours ethnographique. Québec: Septentrion.

Pagden, A. (1987). The fall of natural man. The American Indian and the origins of comparative ethnology. Cambridge: Cambridge University Press.

Paschoud, A. (2008). De la représentation de l'origine à la défense de la foi. L'usage des gravures dans les Mors des Sauvages amérquains comparées aux mors des premiers temps (1724) de Jean-Joseph [sic !] Lafitau. In E. Flamarion (Ed.), La chair et le verbe : Les jésuites de France au XVIIIe siècle et l'image (pp. 75-89). Paris: Sorbonne Nouvelle

Pomian, K. (1987). Collectionneurs, amateurs et curieux: Paris, Venise (XVIe-XVIIIe siècle). Paris: Gallimard.

Roger, J. (1993). Les sciences de la vie dans la pensée française au XVIIle siècle. Paris: Albin Michel.

Smith, P. H., Meyers, A. R. W., \& Cook, H. J. (Eds.). (2017). Ways of making and knowing. The material culture of empirical knowledge. New York: Bard Graduate Center.

Verreau, H. (1858). Le Père Lafitau et le Gin-Seng. In Mémoire présenté à son Altesse royale Monseigneur le duc d'Orléans, Régent du royaume de France: concernant la précieuse plante du ginseng de Tartarie, découverte en Canada par le père Joseph-François Lafitau, de la Compagnie de Jésus, missionaire des Iroquois du Sault Saint-Louis, Nouvelle Edition, Précédée d'une notice biographique par M. Hospice Verreau (pp. 3-39). Montreal: Typographie du Senecal, Daniel et Compagnie

Voltaire, . (1963). Essai sur les mours et l'esprit des nations. Paris: Garnier.

Waquet, F. (2015). L'ordre matériel du savoir. Comment les savants travaillent, XVIe-XXIe siècles. Paris: CNRS Éditions

Warwick, J. (1996). Lafitau. Mémoire sur le ginseng. In G Bérubé (Ed.), La lettre au XVIIIe siècle et ses avatars (pp. 201-208). Toronto: Éditions du GREF

Publisher's Note Springer Nature remains neutral with regard to jurisdictional claims in published maps and institutional affiliations. 